\title{
Spatio-temporal distribution and target species of longline fisheries off Southeastern/Southern Brazil between 2000 and 2011
}

\author{
Fernando N. Fiedler ${ }^{1, *}$, Gilberto Sales ${ }^{2}$, Bruno B. Giffoni ${ }^{3}$, Dagoberto Port ${ }^{1}$, Rodrigo Sant'Ana ${ }^{4}$, \\ André Silva Barreto ${ }^{1}$, Paulo Ricardo Schwingel ${ }^{1}$
}

\author{
(Rua Uruguai 458, CEP: 88302-202, Itajaí, SC, Brasil) \\ ${ }^{2}$ Centro TAMAR/ICMBio. \\ (Av. Ministro Victor Konder 374, CEP: 88301-700, Itajaí, SC, Brasil) \\ ${ }^{3}$ Fundação Pró-TAMAR. \\ (Rua Antônio Athanazio da Silva 273, CEP: 11680-000, Ubatuba, SP, Brasil) \\ ${ }^{4}$ Projeto ALBATROZ. \\ (Rua Uruguai 458, CEP: 88302-202, Itajaí, SC, Brasil)
}

${ }^{1}$ Universidade do Vale do Itajaí (UNIVALI), Programa de Pós Graduação em Ciência e Tecnologia Ambiental (PPCTA)

*Corresponding author: fnfiedler@hotmail.com

Financial Support: Coordenação de Aperfeiçoamento de Pessoal de Nível Superior - CAPES - Brasil (Edital Ciências do Mar 09/2009 Projeto IGEPESCA).

\section{Abstract}

In the presente study, cluster analysis was performed to classify 1080 interviews with captains of national pelagic longline fleet (2000 to 2011), and 38 trips of the chartered fleet (2003 to 2008), in relation to the composition of species landed. For the national fleet 4 groups were identified: 1 - Albacores, 2 - Blue shark, 3 - Swordfish, and 4 - Dolphinfish. For the chartered fleet 3 groups were identified: 1 - Swordfish, 2 Blue shark, and 3 - Albacores. The results indicated that part of the national fleet change their strategies according to the availability of the target species and market demand (internal and external). A part of the fleet from Espírito Santo state operates in the region between December and March, exclusively to capture dolphinfish. The chartered fleet differed from the national one as regards the fishing areas of each target species, mainly as regards swordfish and blue shark. Despite the great difference in the data sets, it is evident that both the national and the chartered fleets operated in accordance with their peculiarities and technological development, adopting strategies that optimize catches and net profits per trip.

Descriptors: Longline fisheries, Fishing effort, Target species, Fishing strategy, National and Foreign fleet, Fleet dynamics.

\section{RESUMO}

No presente estudo, uma análise de agrupamento foi realizada para classificar 1080 entrevistas com mestres da frota nacional de espinhel pelágico (2000 à 2011), e 38 embarques da frota estrangeira arrendada (2003 a 2008), em relação à composição das espécies desembarcadas. Para a frota nacional, foram identificados 4 grupos: 1 - Albacoras; 2 - Tubarãoazul; 3 - Meca; e 4 - Dourado. Para a frota estrangeira arrendada foram identificados 3 grupos: 1 - Meca; 2 Tubarão-azul; e 3 - Albacoras. Os resultados indicam que parte da frota nacional altera suas estratégias de pesca de acordo com a disponibilidade da espéciealvo e pela demanda do mercado (interno e externo). Uma parcela da frota oriunda do Espírito Santo opera na região durante alguns meses de verão (dezembro a março), exclusivamente na captura do dourado. Para a frota estrangeira arrendada, ocorrem diferenças principalmente nas áreas de pesca para cada uma das espécies, sendo a frota direcionada principalmente para a captura da meca e tubarão-azul. Apesar da grande diferença no conjunto de dados, fica evidente que a frota nacional e estrangeira operam de acordo com suas particularidades e desenvolvimento tecnológico, adotando estratégias que otimizem as capturas e os lucros líquidos por viagem.

Descritores: Pescarias de espinhel, Esforço pesqueiro, Espécies-alvo, Estratégia de pesca, Frota Nacional e Estrangeira, Dinâmica da frota. 


\section{INTRODUCTION}

The pelagic longline is fishing gear that uses a main line sustained by buoys, to which are fixed secondary lines with hooks. This fishery is primarily directed to the capture of albacores (Thunnus alalunga, T. obesus, T. albacares), swordfish (Xiphias gladius) and sharks (specially Prionace glauca) (BROTHERS et al., 1999; WATSON; KERSTETTER, 2006), species which are of great economic importance worldwide because of their high market value (EVANGELISTA et al., 1998; HAZIN, 2006), for both the flesh and, as in the case of sharks, the fins (MAZZOLENI; SCHWINGEL, 1999; QUAGGIO et al., 2008).

In Brazil this fishery started in 1956 (PAIVA, 1961) with the arrival of Japanese vessels at the port of Recife, state of Pernambuco (PE), northeastern Brazil, where they continued to fish until 1964 (MENEZES DE LIMA et al., 2000). In southeastern Brazil, this fishery, undertaken by national vessels based on Santos, state of São Paulo (SP), started in 1958 (MAZZOLENI; SCHWINGEL, 2002). In the southern region this fishery began in 1959 with chartered Japanese vessels (HAIMOVICI, 1997). Since then, successive changes have occurred in relation to the flags of the fleets acting in Brazilian waters (EVANGELISTA et al., 1998), with a gradual increase in the number of vessels over the years (AMORIM et al., 2002). Currently, in southeastern/southern Brazil - SE/S $\left(20^{\circ} \mathrm{S}\right.$ to $\left.40^{\circ} \mathrm{S}\right)$, this fishery is based primarily on the ports of Itaipava, state of Espírito Santo (ES), Santos (SP), Itajaí, state of Santa Catarina (SC) and Rio Grande, state of Rio Grande do Sul (RS) (SALES et al., 2008), from which only national vessels operate. Chartered vessels have been leased to the northeast, mainly to catch albacores.

The strategies used to capture target species are based not only on biological and technological factors, but also on distinct forms of operation. Preferences, skills, perceptions and access to resources play a fundamental role in the success of the catch and the distribution of fishing effort (SALAS; GAERTNER, 2004). These strategies are one of the most important factors that affect Catch Per Unit Effort - CPUE (HE et al., 1997).

In Brazil, different strategies and fishing technology have been employed by the pelagic longline fleet since the beginning of its activities in the 1950s (MENEZES DE LIMA et al., 2000). These strategies have altered over the years in accordance with market changes and the introduction of new equipment (HAZIN et al., 2007a). Furthermore, these strategy shifts directly influence catch rates and hence the abundance of particular species (RICKER, 1975). Because of this, the national and chartered fleets that have operated in the SE/S region have modified their target species over time on the basis of resource availability and more efficient market strategies, thus ensuring the success and development of this activity.

Clustering methods (e.g. cluster analysis) are applied to fishing data as a way to determine the strategies used to capture target species. These methods categorize fishing effort based on the proportion of species caught and thus detect changes in strategies of capture (ROGERS; PIKITCH, 1992; LEWY; VINTHER, 1994; HE et al., 1997; WU; YEH, 2001; HAZIN et al., 2007a). This method is very efficient especially in commercial fisheries with multiple target species, on which it is not always possible to obtain information from the behavior of the fleets on their fishing trips (CARVALHO et al., 2010).

This study aimed to categorize the effort and fishing strategies adopted by both national and chartered pelagic longline fleets operating from Itajaí harbor (SC) in the SE/S region of Brazil and adjacent waters between 2000 and 2011, based on the proportions of species landed.

\section{MATERIAL AND METHODS}

The information used in this study was obtained from two different monitoring programs conducted by the Fisheries Study Group (GEP) of the Universidade do Vale do Itajaí - UNIVALI. Information concerning the national longline fleet was obtained from the Fisheries Statistical System - SIESPE, while information regarding the chartered fleet was collected by Onboard Observers Program - PROA, both conducted by UNIVALI through scientific technical agreements with the federal government.

Fishing information was first organized into two matrices considering both fleets (i.e. national and chartered), the number of landings of each fleet monitored (i.e., 1080 cruises of the national fleet and 38 cruises of the chartered fleet were arranged in the rows of this matrix - Table 1) and the proportion of species and/or more frequent groups present in the catch of both fleets (Table 2). These matrices were used to identify fishing operations patterns and searches for similar target species among different vessels in separate for both national and chartered fleet. Thus with a view to classifying capture patterns and operating strategies, a multivariate approach based on hierarchical cluster analysis was conducted 
centered on Ward's method of minimum variance (WARD, 1963). This method consists of maximizing the search for homogeneity within groups as they are formed. The groups are, therefore, formed by the process in which the sum of the squares of the internal residuals is minimized (HAIR, 2005; BORCARD et al., 2011). In such a manner as to identify the significance of the groups formed by the hierarchical cluster analysis, three distinct approaches were implemented: an Analysis of Similarity (CLARKE, 1993), a Multi-response Permutation Procedure (MIELKE; BERRY, 2001) and a Permutational Multivariate Analysis of Variance (ANDERSON, 2001). This kind of combined analysis, based on distinct assumptions, allows a better understanding of the significance of the groups formed by the cluster analysis, mainly as regards the different sensibilities of each kind of approach used.

Table 1. Number of trips by national and chartered longline fleets that operated between 2000 and 2011 in southeastern/ southern Brazil.

\begin{tabular}{ccc}
\hline \multirow{2}{*}{ Year } & \multicolumn{2}{c}{ Number of Trips } \\
& National Fleet & 0 \\
\hline 2000 & 8 & 0 \\
2001 & 63 & 0 \\
2002 & 72 & 2 \\
2003 & 65 & 5 \\
2004 & 42 & 15 \\
2005 & 77 & 15 \\
2006 & 168 & 0 \\
2007 & 139 & 1 \\
2008 & 117 & 0 \\
2009 & 116 & 0 \\
2010 & 87 & 0 \\
2011 & 126 & 38 \\
Total & 1080 & \\
\hline
\end{tabular}

Later, graphic compositions of the catches of species and/or groups were constructed based on the groups identified by the hierarchical cluster analysis for both the national and chartered fleets studied, thus allowing the identification of the target species in each group previously characterized. To assess the spatial distribution of the fishing strategies of these fleets, spatial analysis was also conducted with regard to the groups formed in the cluster analyses. Fishing areas were standardized into a common research unit for both fleets (national and chartered) assumed as spatial quadrants of $30 \times 30$ minutes of resolution. This procedure allowed spatial dynamic
Table 2. Common name/groups and scientific name/ family caught by national and chartered longline fleets off southeastern/southern Brazil (above $20^{\circ} \mathrm{S}$ ) between 2000 and 2011.

\begin{tabular}{ll}
\hline Common name/Group & Scientific name/Family \\
\hline \multirow{3}{*}{ Albacore } & Thunnus alalunga \\
& $\begin{array}{l}\text { Thunnus obesus } \\
\text { Thunnus albacares }\end{array}$ \\
\hline Swordfish & Xiphias gladius \\
Blue Shark & Prionace glauca \\
Dolphinfish & Coryphanea hippurus \\
\hline \multirow{3}{*}{ Other Sharks } & Family Carcharhinidae, \\
& Edontaspididae, \\
& Mitsukurinidae, Lamnidae, \\
& Alopiidae, Squalidae, \\
& Triakidae, Rajidae, \\
& Dasyatidae \\
\hline Other Fishes & Family Istiophoridae, \\
& Serranidae, Scombridae, \\
& Gempylidae \\
\hline
\end{tabular}

comparison of the two fleets, as well as the visualization of fishing areas with higher and/or lower effort concentration.

The effort dynamics and operation strategies of these fleets (e.g. number of days at sea, number of fishing days, number and immersion time of hooks) were analyzed through time as well as in terms of the groups observed in the previous cluster analysis - adjusted to determine possible strategic shifts in the fishing operations directed to each target species.

All the analyses presented in this study were carried out on an open source, free distribution software R 3.0.3 (R DEVELOPMENT CORE TEAM, 2014). Bathymetric data were derived from ETOPO1 as acquired from the databases of the National Oceanic and Atmospheric Administration - NOAA accessed via the marmap package available for R (PANTE; SIMON-BOUHET, 2013).

\section{RESULTS}

\section{NATIONAL FLEET}

Hierarchical cluster analysis was able to identify four distinct groups in terms of the fishing strategies (ANOSIM - $\mathrm{R}=0.9287, p$-value $=0.0009 ;$ MRPP $-\mathrm{A}=0.5964$, $p$-value $=0.0009 ;$ PERMANOVA $-\mathrm{F}=1055, \mathrm{DF}=3$, $p$-value $=0.0009 ;$ Cophenetic correlation index $=0.856$ ) adopted by the national pelagic longline fleet operating in Santa Catarina between 2000 and 2011 (Figure 1). 


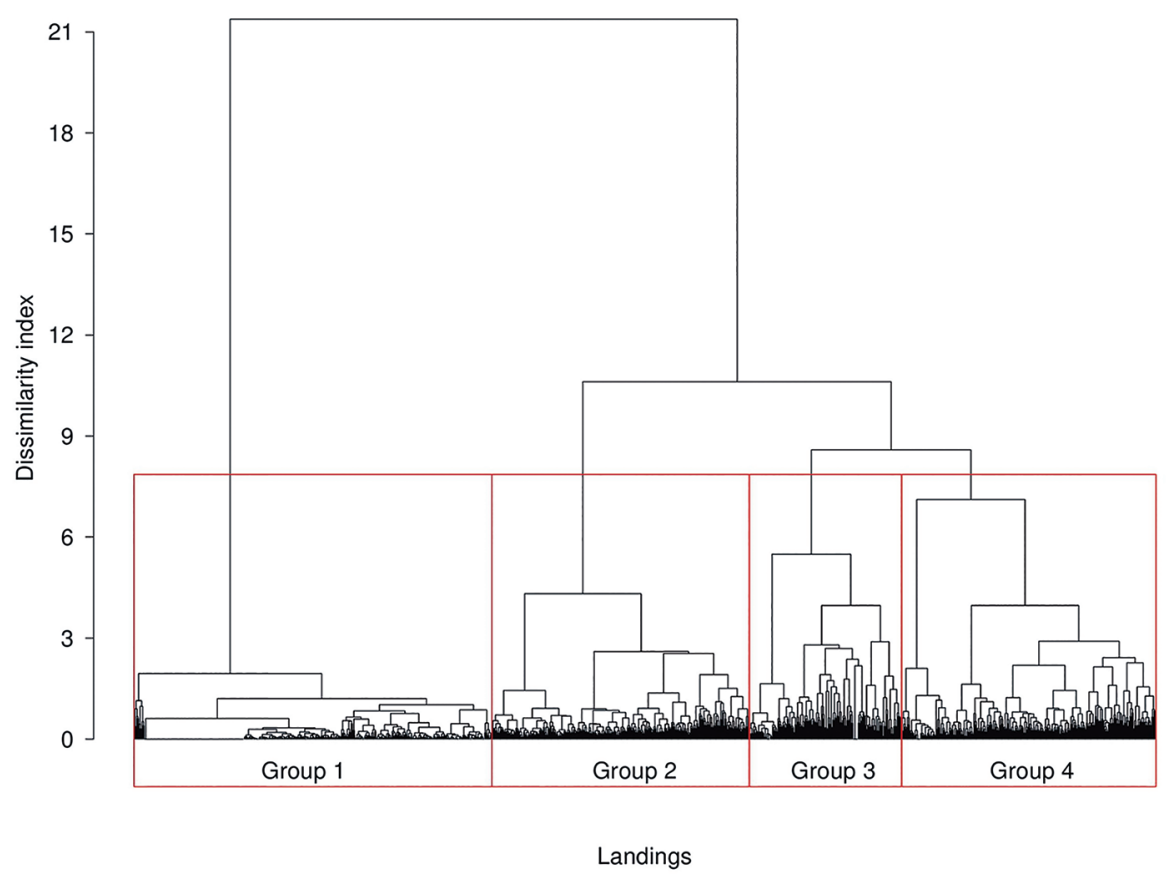

Figure 1. Dendrogram of fish landings considering species composition as a proportion landed of each specie per trip in the national pelagic longline fleet in the state of Santa Catarina between 2000 and 2011. Cluster analysis based on Ward's method and Euclidean dissimilarity coefficient. Group 1: Albacores; Group 2: Blue shark; Group 3: Swordfish; Group 4: Dolphinfish.

These groups were formed from the species and/ or groups of species of greatest interest for each vessel on each fishing trip. Group 1 directed to the captures to albacores (Thunnus obesus, T. alalunga and $T$. albacares), with approximately $46 \%$ of total Group production; Group 2 directed to the capture of the blue shark (Prionace glauca), with approximately $67 \%$ of total Group production; Group 3 focused on the capture of the swordfish (Xiphias gladius), with approximately $42 \%$ of total production; and Group 4 directed to the capture of dolphinfish (Coryphaena hippurus), which represented about $96 \%$ of the total Group production (Figure 2).

The spatial distribution of this fleet indicates extensive use of the entire area over the continental shelf and slope areas off SE/S Brazil, including international waters, with emphasis on the Rio Grande Rise (Figure 3). The fishery directed to albacores (Group 1), although there are some trips to oceanic regions, demonstrates a pattern in the use of the external continental shelf and slope waters of São Paulo and Rio Grande do Sul states. The captures of blue shark (Group 2) and swordfish (Group 3) over the outer continental shelf and slope areas between the states of Rio de Janeiro and Rio Grande do Sul is shown to be important, including the oceanic region and on the Rio Grande Rise. The fishery directed to the dolphinfish (Group 4), occurred in more coastal regions, between Espírito Santo and Rio Grande do Sul states. This feature is related to the distribution area of the target species, as well as limited by the smaller size of the vessels used. In general, the depths of operation for the national longline fleet, considering the 4 different fisheries identified throughout the historical series, ranged from 50 to $6000 \mathrm{~m}$.

The distribution of effort in days at sea, fishing days and total number of hooks observed over the years showed that between 2000 and 2002 the central tendency of these variables (median), in general, was higher than the observed pattern in other years. From 2003 onwards, effort patterns of this fleet were shown to be stable (Figure 4).

The effort on days at sea, fishing days and total number of hooks used, discriminated by fishery shows that Groups 1, 2 and 3 presented a similar pattern of operation in equivalent areas to capture the different resources. However, Groups 2 and 3, in general, showed an effort in days at sea and fishing days a little higher than that of Group 1, because they also use oceanic areas and the Rio Grande Rise as fishing areas. Group 4 showed a lower effort in days at sea, certainly influenced by the autonomy of vessels, fishing strategy and the close proximity to areas of target species concentration (Figure 5). 


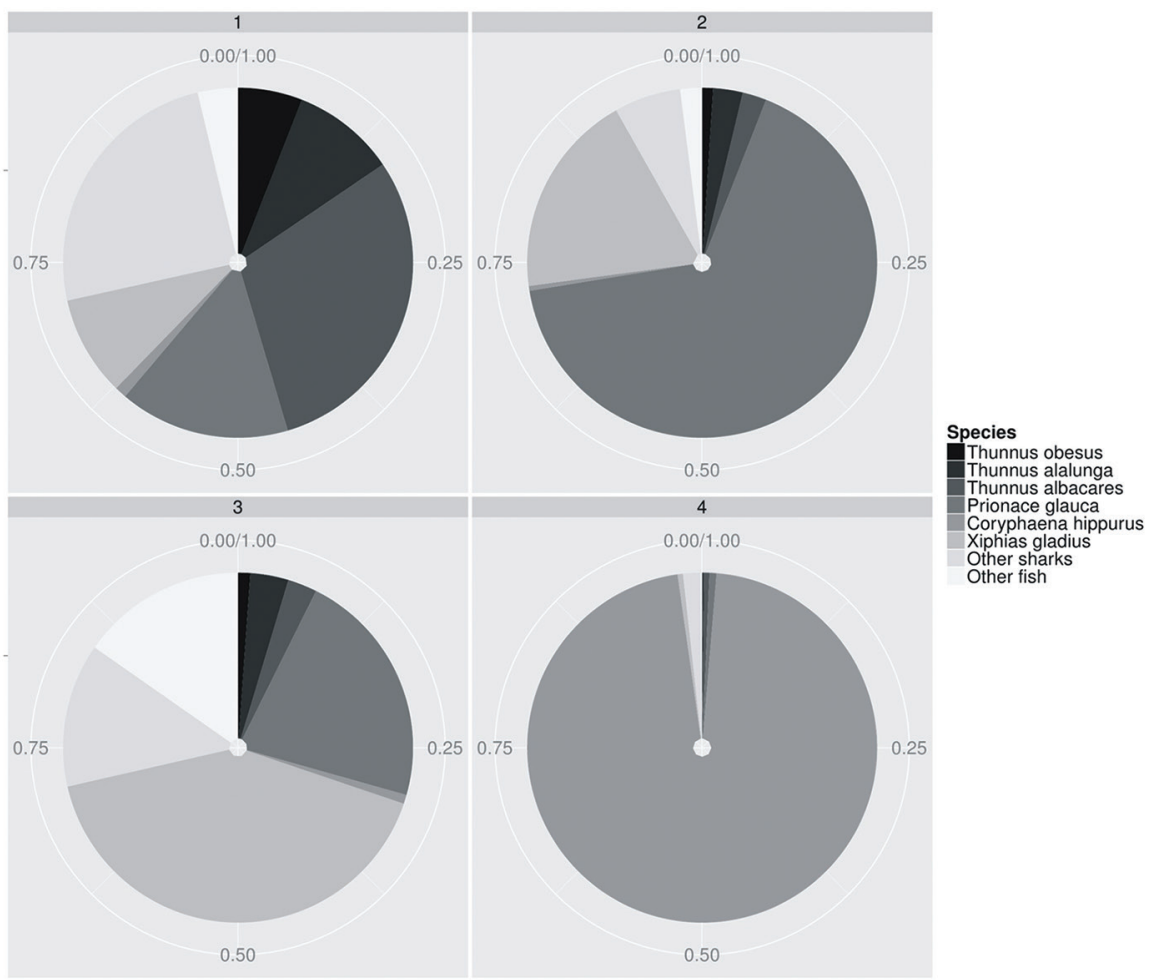

Figure 2. Proportions capture species landed by each of the groups identified in the clustering analysis. Group 1: Albacores; Group 2: Blue shark; Group 3: Swordfish; Group 4: Dolphinfish.

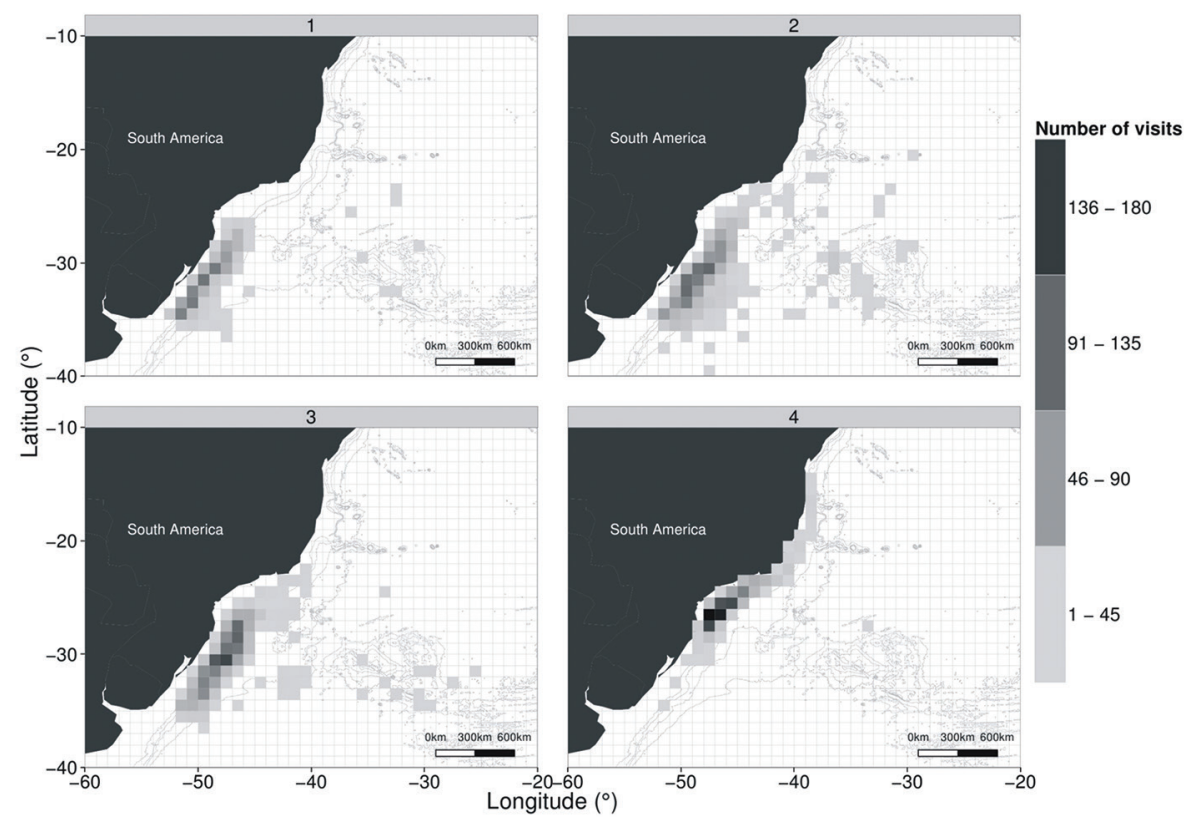

Figure 3. Density distribution of the areas visited by each group of national pelagic longline fleet between 2000 and 2011. Lines represent the isobaths of 1000, 2000, 3000 and 4000 meters. Bathymetric data were obtained from ETOPO1, as acquired from the databases of the National Oceanic and Atmospheric Administration - NOAA accessed via marmap package for R (PANTE \& SIMON-BOUHET, 2013). Group 1: Albacores; Group 2: Blue shark; Group 3: Swordfish; Group 4: Dolphinfish. 

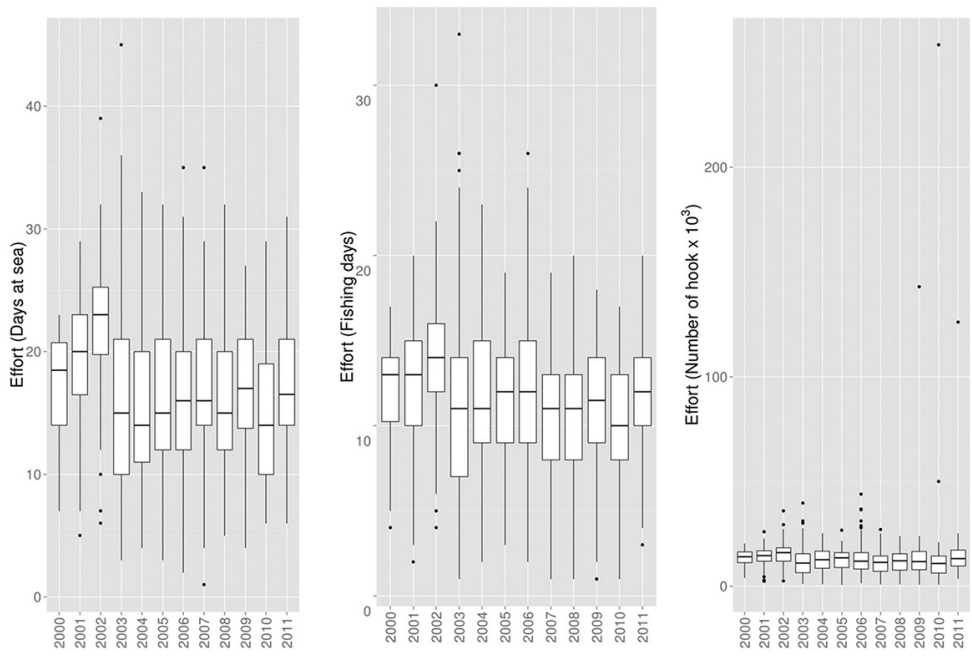

Figure 4. Box-plot of the total effort in days at sea, fishing days and number of hooks for the national pelagic longline fleet, grouped for each year between 2000 and 2011.
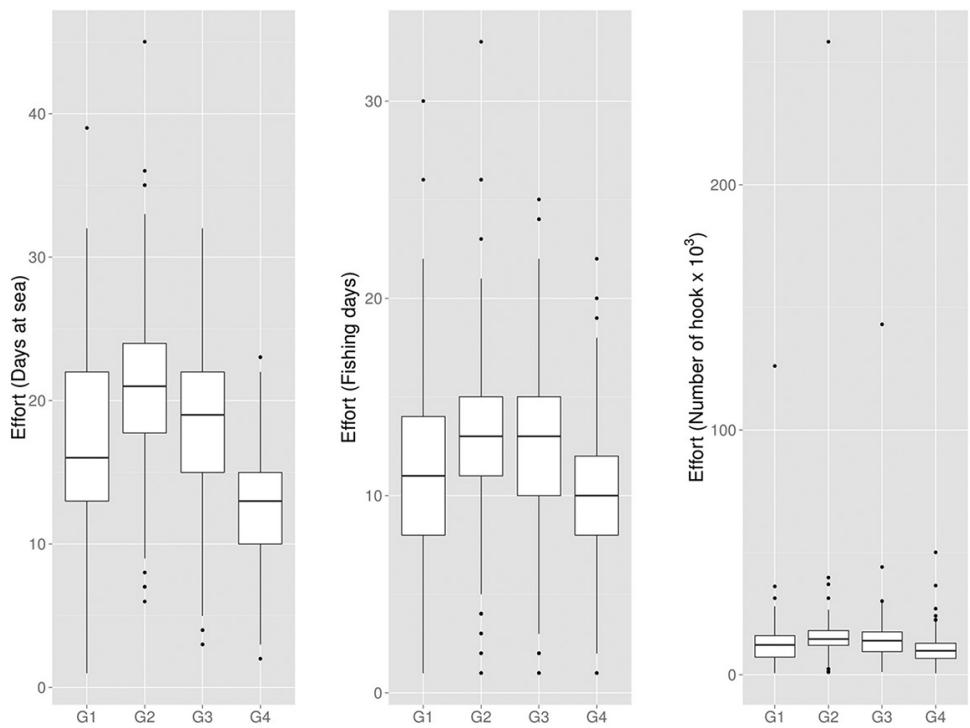

Figure 5. Box-plot of total effort in days at sea, fishing days and number of hooks for each of the groups of national pelagic longline fleet grouped for each year between 2000 and 2011. Group 1: Albacores; Group 2: Blue shark; Group 3: Swordfish; Group 4: Dolphinfish.

Total effort in number of days at sea, fishing days and total number of hooks used by each of the fisheries identified between the years 2000 and 2011, showed distinct moments of shifts in operating strategy and fleet interest (Figure 6). In Group 3 a large increase in effort in days at sea, fishing days and total number of hooks was observed at the beginning of the decade (2000-2003), followed by a sharp decrease in the following years (between 2003 and 2005). From 2005 it was possible to discern the growth of a new fishery, directed to dolphinfish, which at the beginning of the series presented a lesser effort than the other groups.
The reduction in the fishing effort directed to the capture of swordfish (Group 3) resulted in the development of other fisheries (Figure 6), and from 2005, fisheries directed to albacores (Group 1), blue shark (Group 2) and dolphinfish (Group 4) became more evident. Another important factor is that, because of their high commercial value, the fishery directed to albacores at any one time concentrated more interest in terms of fishing effort. In general, the fishery for albacores (Group 1) remained in fourth place on a scale of targeting effort, unlike other fisheries of this fleet, which alternated on a scale of attention and targeting (Figure 6). 

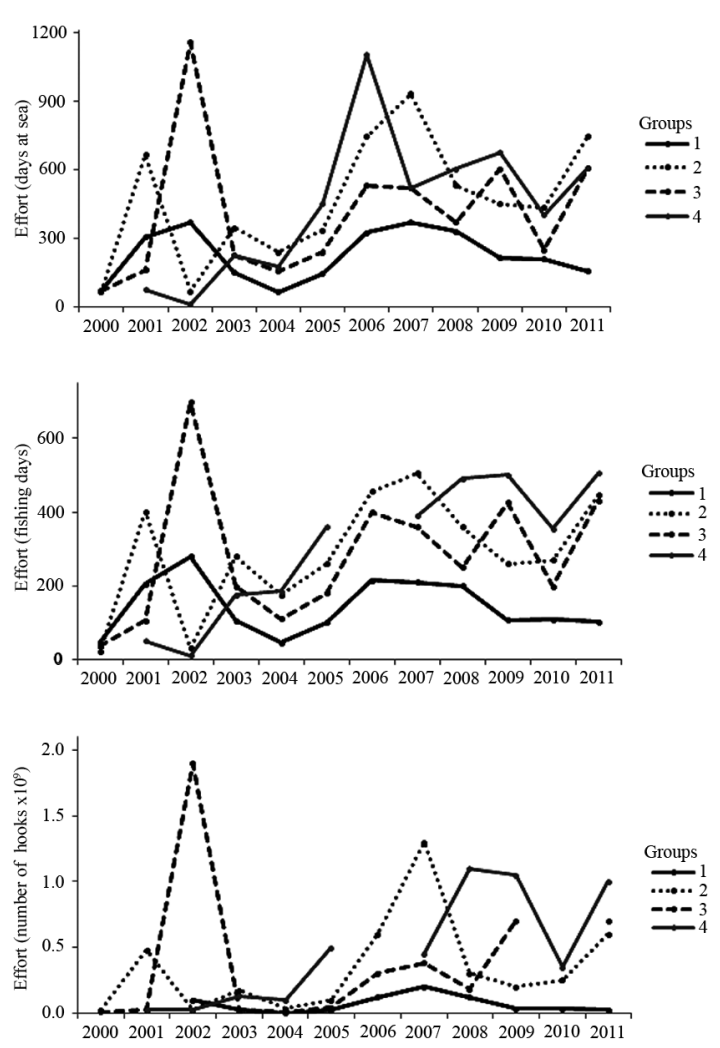

Figure 6. Total effort in days at sea, fishing days and number of hooks for each of the groups of national pelagic longline fleet between 2000 and 2011. Interruptions of lines indicate no data for the period. Group 1: Albacores; Group 2: Blue shark; Group 3: Swordfish; Group 4: Dolphinfish.

In relation to soaking time of fishing gear (Figure 7), the fisheries directed to albacores (Group 1), blue shark (Group 2) and swordfish (Group 3) presented a standard average time of 12 hours. However, Group 1 showed the greatest variation in soaking time. In Group 4 (dolphinfish), despite the fact that data showed a standard of 7.5 hours of immersion, a large variation was observed due to the different operating strategies adopted by this fleet.

\section{Chartered Fleet}

The hierarchical cluster analysis showed the presence of three distinct fisheries (ANOSIM - $\mathrm{R}=\mathrm{s} 0.6187$, $p$-value $=0.0009 ;$ MRPP $-\mathrm{A}=0.2898, p$-value $=0.0009$; PERMANOVA - $\mathrm{F}=18636, \mathrm{DF}=2, p$-value $=0.0009$; Cophenetic correlation index $=0.647$ ) for the chartered pelagic longline fleet that operated in SE/S Brazil and was monitored by onboard observers from PROA between 2003 and 2008 (Figure 8). These groups were formed on the basis of the species and/or groups of species of the greatest interest for each vessel on each fishing trip, Group 1 being directed to capture the swordfish (Xiphias gladius), with approximately $68 \%$ of the total Group production; Group 2 directed to capture the blue shark (Prionace glauca), with around $41 \%$ of the total production of the Group; and the Group 3 focused on albacores (Thunnus obesus, T. alalunga and T. albacares) with approximately $50 \%$ of total production in the Group (Figure 9).

Although the monitored number of cruises of this fleet is lower than the national fleet, spatial data distribution (Figure 10) showed patterns distinct from those of the national fleet, indicating a greater use of more oceanic areas, as in the case of the Vitoria-Trindade Chain, when fleet intended to capture the swordfish (Figure 10 - Group 1). The fishery directed to blue shark (Group 2) was otherwise concentrated in the outer areas of the continental slope and the Rio Grande Rise (Figure 10 - Group 2). In the case of the fishery directed to albacores (Group 3), the effort was focused only on the shelf break, off the states of Santa Catarina and Rio Grande do Sul (Figure 10 - Group $3)$. In general, the depths of operation of this fleet ranged from 630 to 5300 meters.

In relation to effort in days at sea, fishing days and total number of hooks used, no consistent pattern was observed over the years (Figure 11), mainly due to the variation in the number of operating vessels and the search for target species. It should be noted that the variation in the number of vessels operating in this region over the years is directly linked to the prior authorization from the federal government required to fish. Moreover, in 2008 only one vessel operated in the region, with an effort in days at sea, fishing and total number of hooks performed well above the previous years.

The analysis of fishing effort distribution by fishery (Groups) (e.g. days at sea, fishing days and total number of hooks used) revealed two distinct strategies in patterns of fleet operation, one directed to the capture of the swordfish (Group 1), with relatively larger overall effort employed than that adopted for other fisheries (Groups 2 and 3). In the case of fisheries directed to the capture of the blue shark (Group 2) and albacores (Group 3), fishing patterns were very similar (Figure 12).

Observing the total effort of this fleet in each fishery (e.g. days at sea, fishing days and total number of hooks used), there was considerable fluctuation over the years (Figure 13), possibly affected by the continual incoming and outgoing of vessels. The effort in terms of the total 


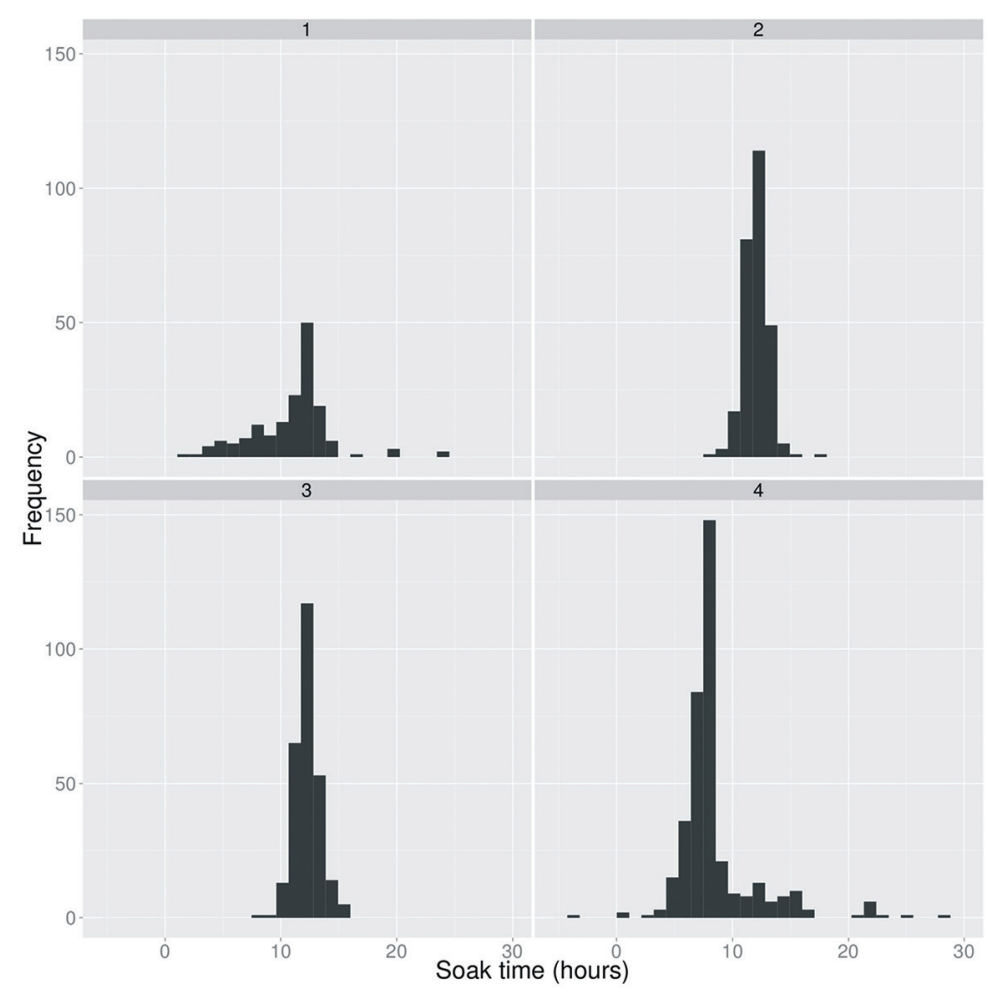

Figure 7. Histogram of soak time of hooks for each groups of national pelagic longline fleet during the study period (2000-2011). Group 1: Albacores; Group 2: Blue shark; Group 3: Swordfish; Group 4: Dolphinfish.

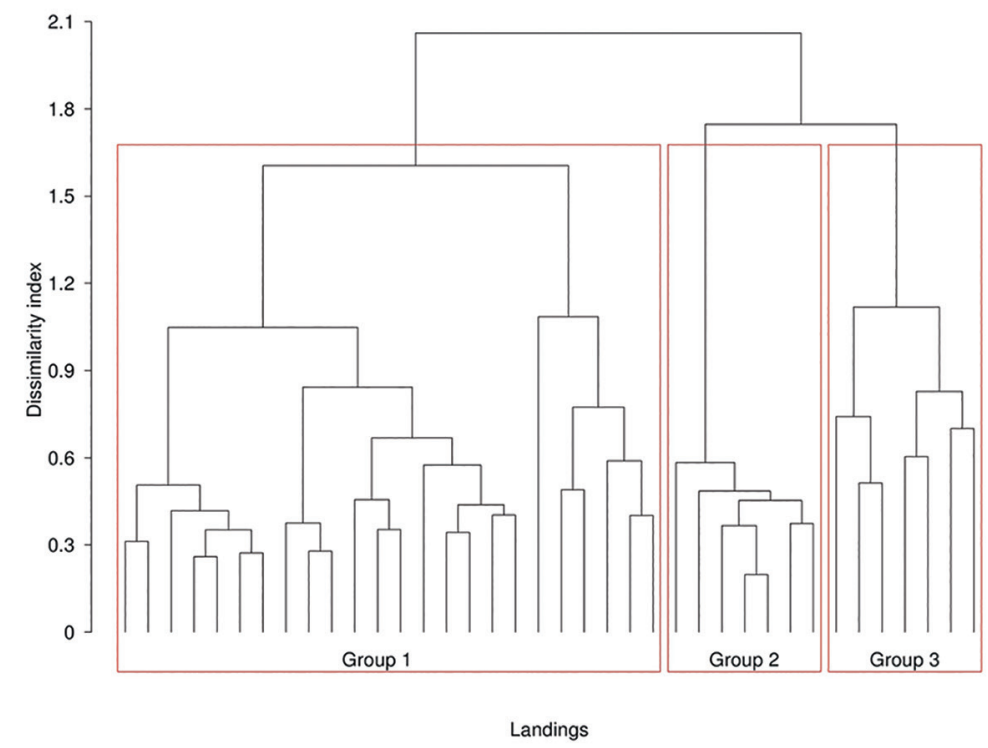

Figure 8. Dendrogram of fish landings considering species composition as a proportion landed of each specie per trip in chartered pelagic longline fleet in the state of Santa Catarina between 2003 and 2008. Cluster analysis based on Ward's method and Euclidean dissimilarity coefficient. Group 1: Swordfish; Group 2: Blue shark; Group 3: Albacores. 


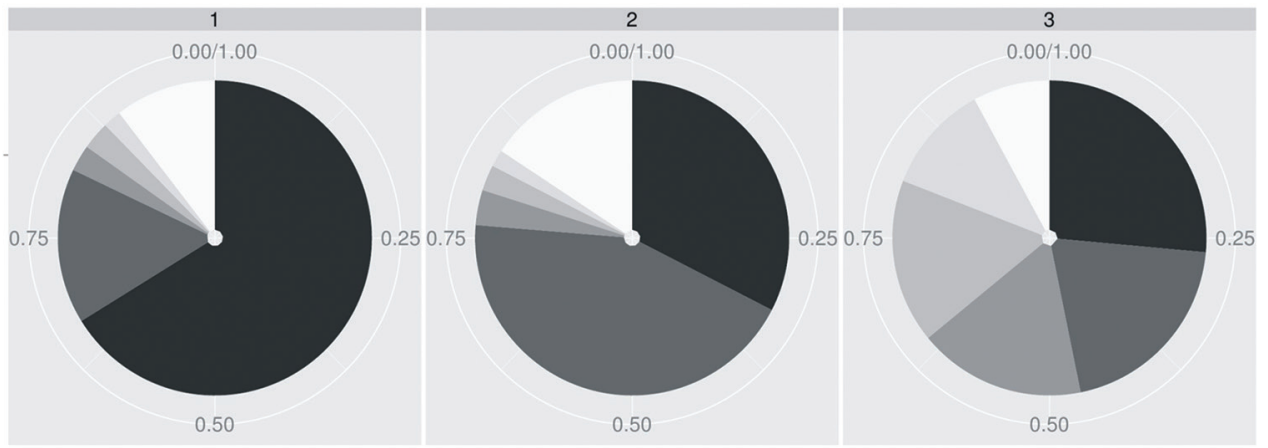

Species $\square$ Xiphias gladius $\square$ Prionace glauca Thunnus alalunga $\square$ Thunnus albacares Thunnus obesus Other sharks

Figure 9. Proportions of landed capture by species in each group identified in the cluster analysis. Group: 1 - Swordfish; Group 2: Blue shark; Group 3: Albacores.

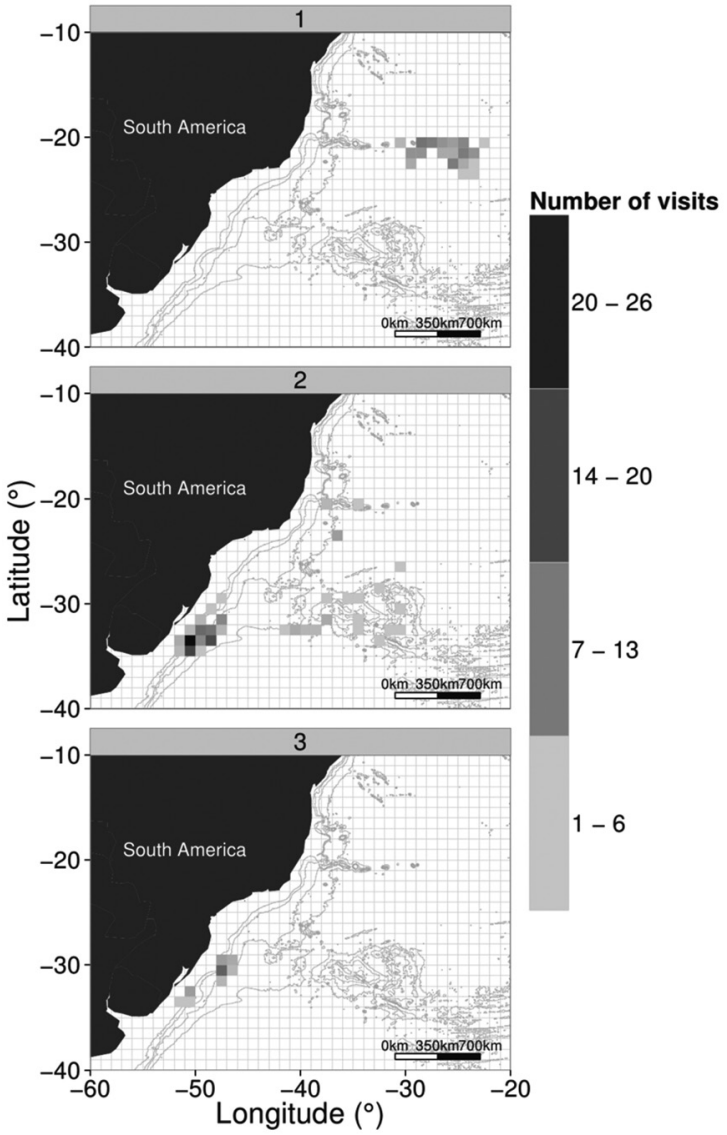

Figure 10. Density distribution of the areas visited by each of the groups of the chartered pelagic longline fleet between the years 2003 and 2008. Lines represent the isobath of 1000, 2000, 3000 and 4000 meters. Bathymetric data were obtained from ETOPO1, as acquired from the databases of the National Oceanic and Atmospheric Administration - NOAA and accessed via marmap package for $\mathrm{R}$ (PANTE \& SIMON-BOUHET, 2013). Group 1: Swordfish; Group 2: Blue shark; Group 3: Albacores. number of hooks is directly related to the strategy adopted by each vessel in its various fisheries. For the blue shark (Group 2), there was a small decrease in effort in days at sea and fishing days between the years 2003 and 2004, but an increased effort occurred in number of hooks used. This pattern continued until 2005, when the total number of hooks achieved a peak. Despite the decrease in the number of vessels, the remaining vessels increased their effort in days at sea, fishing days and total number of hooks. For Group 1 (swordfish), there was initially a great effort in days at sea (approximately 65 days) and fishing days (approximately 55 days). An increasing effort in days at sea was later observed, with a decrease in fishing effort on fishing days and consequently the number of hooks used, due to the distance to the fishing grounds (Trindade and Martin Vaz Archipelago). Between the years 2005 and 2006 a big drop in the total effort occurred. On the other hand, a further increase in effort in days at sea and fishing days occurred between 2006 and 2008, accompanied by a large increase in effort in the total number of hooks.

Group 3 (albacores) maintained a certain stability in the patterns of effort in days at sea and fishing days between the years of 2005 and 2006. Additionally, it was possible to distinguish a gradual increase in effort in the total number of hooks used, a characteristic that may be associated with the good catch rates obtained for the target species of this fishery.

Considering the soak time over the years (Figure 14), the data showed low variation due to the change of target species. In general, the immersion pattern of hooks ranged between 10 and 13 hours. 

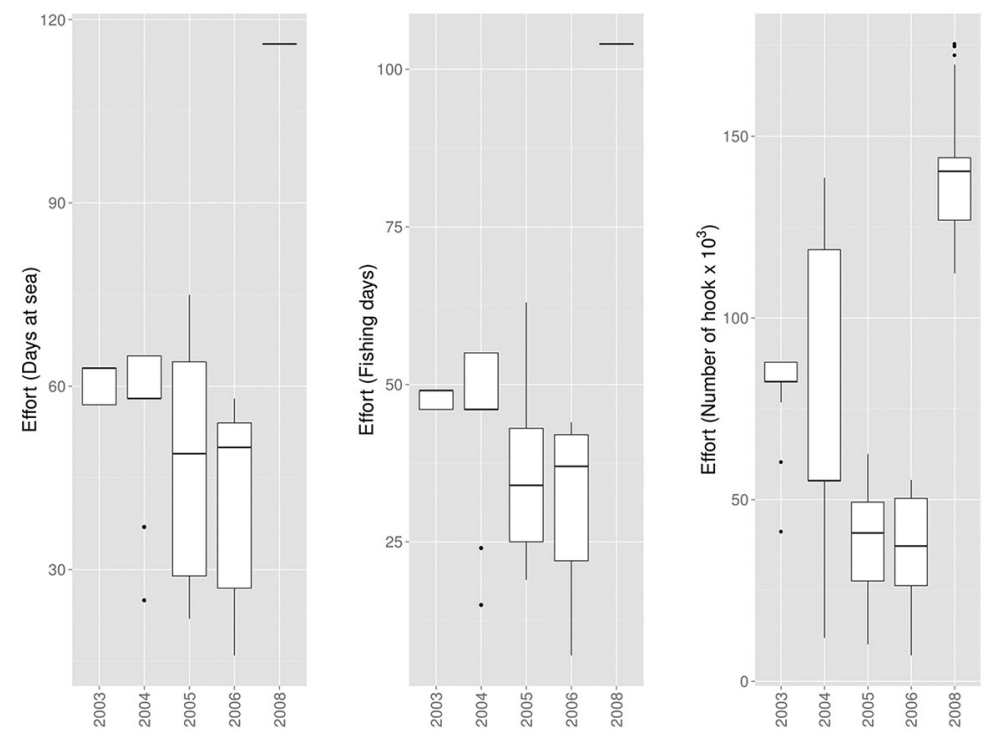

Figure 11. Box-plot of the total effort in days at sea, fishing days and number of hooks of chartered fleet of pelagic longline grouped for each of the years between 2003 and 2008.
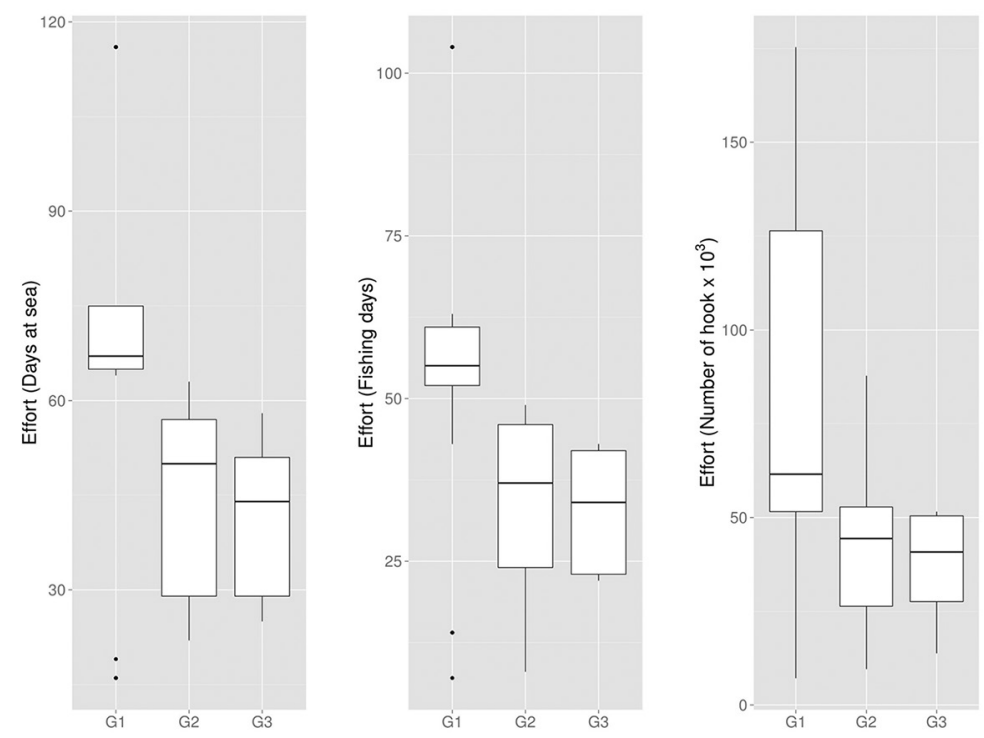

Figure 12. Box-plot of total effort in days at sea, fishing days and number of hooks for each of the groups of chartered pelagic longline fleet grouped for each year between 2003 and 2008. Group 1: Swordfish; Group 2: Blue shark; Group 3: Albacores.

\section{DISCUSSION}

According to CADDY and GRIFFITHS (1996), most of the fish production of the country takes place within 200 miles of the coast (territorial waters). In SE/S Brazil, trawling fleets, seines, traps, gillnets and longlines are the resources used by the industrial fishing activity (CERGOLE et al., 2005).

National pelagic longline fleet used different areas, ranging from the northeast region to international waters, but always kept within the region between $20^{\circ} \mathrm{S}$ (VitóriaTrindade Chain) and $35^{\circ} \mathrm{S}$ (Maldonado, Uruguay) as their main area of activity (MENEZES DE LIMA et al., 2000). Apart form that, distant oceanic areas (e.g. the Rio Grande Rise) are used intensely during the summer months (December to March) when ocean conditions are more favorable (MAYER; ANDRADE, 2003; GIFFONI et al., 2008; MOURATO et al., 2011). In general, national pelagic longline fleet based on the port of Itajaí (SC) use all the SE/S regions as their main fishing area. 

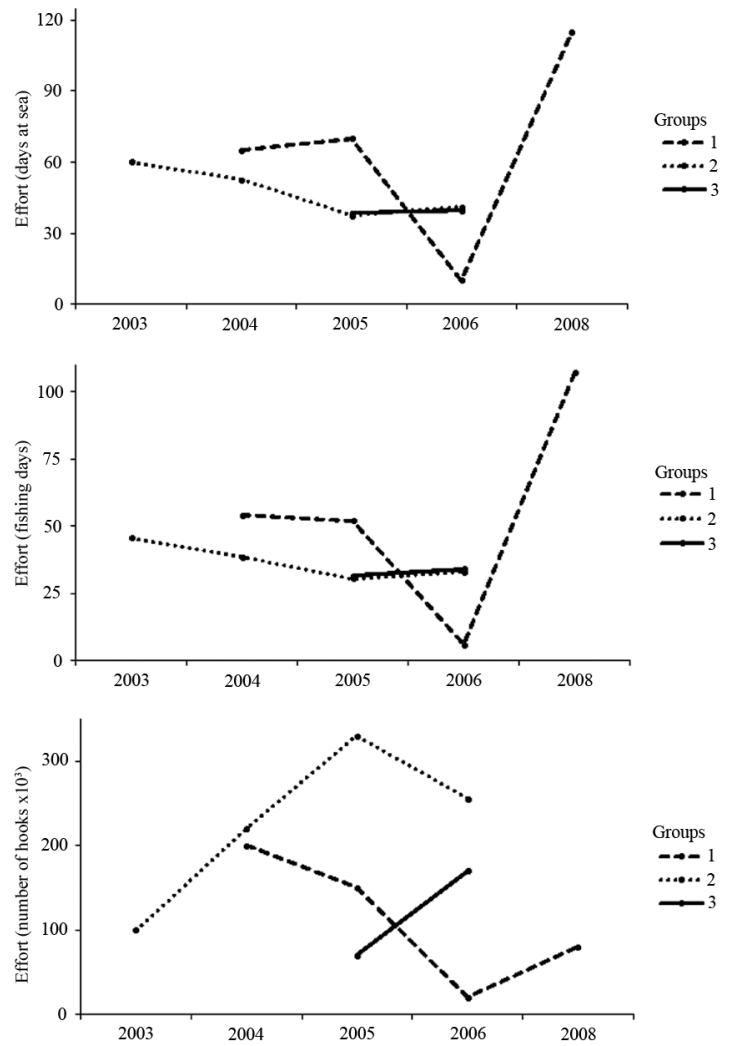

Figure 13. Total effort in days at sea, fishing days and number of hooks for each of the groups of chartered pelagic longline fleet between the years of 2003 and 2008. Group 1: Swordfish; Group 2: Blue shark; Group 3: Albacores.

The composition of species landed by national fleet over the period studied corroborates the data given in other studies in the region (MENEZES DE LIMA et al., 2000; SCHWINGEL; MAZZOLENI, 2004; SALES et al., 2010; MOURATO et al., 2011). This composition reflects the interest of each vessel on each fishing trip in particular target species. Groups 1 (albacores), 2 (blue shark) and 3 (swordfish) are basically landed by the same vessels that alter their fishing strategies and areas according mainly to the availability of the resource and the market value (national and international) of each species (MENEZES DE LIMA et al., 2000; HAZIN et al., 2007a). During summer months, a different fleet moves from the region of Itaipava (Espírito Santo) to seek dolphinfish (Group 4) from the port of Itajaí (DALLAGNOLO; ANDRADE, 2008). These latter authors reported that during 2005, this fleet accounted for $70 \%$ of all dolphinfish landed, with approximately $96 \%$ of this landing occurring during a three-month period (December, January and February).

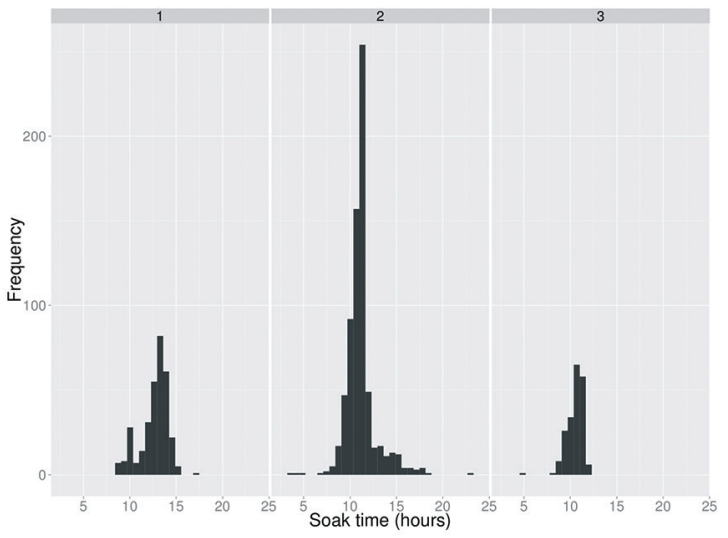

Figure 14. Histogram of soak time of hooks for each of the groups of chartered pelagic longline fleet between 2003 and 2008. Group 1: Swordfish; Group 2: Blue shark; Group 3: Albacores.

For the chartered fleet, despite the lower number of vessels and trips monitored, the greater concentration of effort in specific regions was evident. Group 1 (swordfish) operated primarily on the Vitória-Trindade Chain referred to one trip made by a vessel in 2008, totaling 104 fishing days. Because of this great effort, cluster analysis separated a group for this species. The region of the Vitória-Trindade Chain is an important area for longline fishing, the presence of foreign vessels, both legalized and clandestine, being constantly reported there (WU; YEH, 2001; PINHEIRO et al., 2010). In Group 2 (blue shark), there was an overlap in the area used by the national fleet, but effort was more concentrated in the region of the shelf break off Santa Catarina and Rio Grande do Sul states. According to MAYER and ANDRADE (2005), this region presents catch rates during the year, which together with the aggregated value due to the fin trade, compensate for the lower market values than those of swordfish and albacores. In Group 3 (albacores) there was an overlapping area with Group 2 (blue shark), but with considerably less effort. This indicates that, when Group 3 operated in SE/S Brazil the efforts expended were not exclusively concentrated on the capture of albacores. An effort concentrated on albacores was observed in the northeast, between latitudes $1^{\circ} \mathrm{N}$ and $20^{\circ} \mathrm{S}$ (HAZIN et al., 2007b).

In Brazil, chartered fleet have historically contributed to the rise of catches of tuna and related species, thus ensuring from the ICCAT (International Commission for the Conservation of Atlantic Tunas) the permanence of or increased catch quotas for each signatory country. This explains why most of the foreign ships operating in the northeast region (UOZUMI; NAKANO, 1994; TEIXEIRA 
et al., 2002) were extremely rich in qualitative terms in the tuna species (WU; YEH, 2001; ROCHA et al., 2001). The part of the chartered fleet fishing in the SE/S region sought to capture swordfish and blue shark, precisely because of their high international price and the aggregated value of their fins (AMORIM; ARFELLI, 1984). According to CARVALHO et al. (2010), since 2001 the national fleet have gradually assimilated the technology for the capture of swordfish, which, allied to favorable market conditions (both national and international) have served as extra incentive to direct efforts to catch this species. The participation of properly leased foreign vessels operating in Brazilian waters has been of fundamental importance both in the expansion of ICCAT quotas as also in the development of the national fleet.

Each of the groups of national and chartered fleets formed demonstrates that the strategies used by the group end up serving to catch species of other groups. Previous studies have shown strong correlations between catches of swordfish with blue shark, and albacore with blue shark, which probably occur because of similarities in the feeding habits and habitat use of these species (CARVALHO et al., 2010; MOURATO et al., 2011). Due to the strategies employed by Group 4 (dolphinfish) of the national fleet (e.g. small depth of submergence of the hook - CAMPOS et al., 1993), there has been a high degree of specialization, resulting in an almost monospecific capture (DALLAGNOLO; ANDRADE, 2008). This specificity was not evidenced in the monitoring program carried out at the port of Itaipava, where there is great variation in the number of species landed (KLIPPEL et al., 2005; MARTINS et al., 2005) arising from the use of different fishing techniques (e.g. bottom longline, pelagic longline for swordfish, hand line and others).

Grouped data regarding effort on days at sea and fishing days of the national fleet demonstrate that, although there was an increase between 2000 and 2002, followed by a subsequent decrease, the figures remained stable over the following years, confirming the results obtained by MAYER and ANDRADE (2003). In relation to the total effort in number of hooks, a fluctuation over the years, related to the continuous incoming and outgoing of vessels each year, corroborates the conclusions of MENEZES DE LIMA et al. (2000) reported in a monitoring study of longline fleet effort between 1972 and 1997. As for the port of Itajaí, these data confirmed the tendency found by UNIVALI/CTTMar (2010), where stability occurred between the years of 2000 and 2005, with a subsequent increase to the year 2009 .
For the chartered fleet, the change in effort is to be explained by the fluctuation in the number of vessels that operated in the region during the period studied. MENEZES DE LIMA et al. (2000) reported this fluctuation as responsible for the variation found in total effort in the 1980s and 90s. This fluctuation is associated with the little interest of companies in the region due to the leasing programs offered by the Federal Government, since the costs are high (TEIXEIRA et al., 2002). The effort expended by the national fleet showed that there were differences among the 4 groups identified. The main difference concerns the effort on days at sea, which is directly related to the fishing area and the vessels autonomy. Because the fishing grounds of Group 4 (dolphinfish) are closer to the coast (DALLAGNOLO; ANDRADE, 2008; MARTINS; DOXSEY, 2006) and the vessels used are smaller (MARTINS et al., 2005), there is a smaller effort in days at sea. However, the total number of hooks used was similar to the other groups', which is certainly related to the strategy adopted - that of using more than one set on a single day (DALLAGNOLO; ANDRADE, 2008; BUGONI et al., 2008).

The similarity in the effort for chartered fleet between Group 2 (blue shark) and 3 (albacores) is to be explained by the performance of vessels in the same fishing area. On the other hand, Group 1 (swordfish) that operates farther from shore (Vitória-Trindade Chain) had a greater effort. The activity of this group in the Trindade and Martin Vaz Archipelago region can be explained by the occurrence of the mature individual swordfish (HAZIN; HERZINI, 2008) present in this region, due to high food concentrations (ZAVALA-CAMIM, 1982), which ensures the income despite the increased effort involved.

The fluctuation of the effort made by national fleet over the years has reflected the operational dynamics of this activity. Groups 1 (albacores), 2 (blue shark) and 3 (swordfish) operate throughout the year, but with significant variations (UNIVALI/CTTMar, 2010), as do the conditions of national and international markets (HAZIN et al., 2007a). In Group 4 (dolphinfish), which operates mainly during the summer months (DALLAGNOLO; ANDRADE, 2008), a gradual increase in effort observed as from 2001 could be related to the migration of vessels arising from the collapse of shrimp and grey triggerfish (Balistes capriscus) fisheries on the coast of Espírito Santo (MARTINS; DOXSEY, 2006). For chartered fleet the fluctuation of the effort is directly related to the incoming and outgoing of vessels 
in the region. In addition, many vessels initially made a survey of the pelagic resources of the region, in order to assess the feasibility of operating there.

The soak time is an important variable for the pelagic longline fishery, because it directly affects capture efficiency (LØKKEBORG, 1990). Due to saturation of the equipment with time occurs the loss of bait (WARD; MYERS, 2007), reducing its attractive power (LØKKEBORG, 1990), or increasing the possibility of fishes' escaping. For national fleet, the average soak time for Groups 1 (albacores), 2 (blue shark) and 3 (swordfish) is approximately 12 hours. However, a greater variation of this time (3-15 hours), certainly related to the time taken by the search for albacores, is motivated by the growing trade in fresh tuna. BIGELOW et al. (2006) in a study conducted in Hawaii also showed that the soak time is increased when the vessels attempt to capture swordfish (between 11 and 28 hours), and albacores (between 13 and 31 hours). A study of the longline fleet based on São Paulo state, found a mean soak time of 20 hours (MOURATO et al., 2011), which is much higher than that recorded in this study. This difference is related to the different strategies adopted by the two fleets (SP and SC) for the capture of the same resources. In Group 4 (dolphinfish) the average soak time was 7.5 hours, differently from DALLAGNOLO and ANDRADE'S (2008) finding of an average 9.4 hours. This difference could be explained both by changes in fishing strategy, which undertakes multiple sets on the same day as by the great variation in soak time adopted by the fleet, which often "check" the longline that remain in the water for several hours. For chartered fleet the standard time for the three groups varied between 10 and 13 hours. Different studies have reported a great variability of soak time worldwide, varying from 3 to 22 hours (LØKKEBORG; PINA, 1997; DONOSO; DUTON, 2010; CARRUTHERS et al., 2011). However, this present study showed a small variation in soak time, revealing that the fleet operated with well-defined catch strategies.

Despite an overlapping of the fishing areas covered by national and chartered fleets, particularities in fishing strategy, the use of specific regions, and the technology used make them distinct. Currently, national fleet have added the necessary knowledge (technological and of behavior of the species) to obtain good yields in different seasons. Nevertheless, studies on the biology of the species are needed to assist in the management of these resources and to ensure the maintenance of the activity.

\section{ACKNOWLEDGEMENTS}

The authors wish to express their thanks to the owners, captains and fishermen of the pelagic longline vessels who provided the field staff with valuable information and to all the onboard observers of GEP-UNIVALI who made this study possible. This study was funded by Coordenação de Aperfeiçoamento de Pessoal de Nível Superior CAPES - Brasil (Edital Ciências do Mar 09/2009 - Projeto IGEPESCA).

\section{REFERENCES}

AMORIM, A. F.; ARFELLI, C. A. Estudo biológico-pesqueiro do espadarte, Xiphias gladius Linnaeus, 1758, no sudeste e sul do Brasil (1971 a 1981). Bol. Inst. Pesca, v. 11, p. 35-62, 1984.

AMORIM, A. F.; ARFELLI, C. A.; BACILIERI, S. Shark data from Santos longliners fishery off southern Brazil (19712000). Col. Vol. Sci. Pap. ICCAT., v. 54, n. 4, p. 1341-1348, 2002 .

ANDERSON, M. J. A new method for non-parametric multivariate analysis of variance. Austral. Ecol., v. 26, n. 1, p. 32-46, 2001.

ANDRADE, H. A. Estrutura do setor industrial pesqueiro no estado de Santa Catarina. Notas Téc. FACIMAR, v. 2, n. 1, p. 17-27, 1998.

BIGELOW, K.; MUSYL, M. K.; POISSON, F.; KLEIBER, P. Pelagic longline gear depth and shoaling. Fish. Res., v. 77, p. 173-183, 2006.

BORCARD, D.; GILLET, F.; LEGENDRE, P. Numerical Ecology with R. New York: Springer, 2011. 301 p.

BROTHERS, N. P.; LØKKEBORG, S. The incidental catch of seabirds by longline fisheries: worldwide review and technical guidelines for mitigation. FAO Fisheries Circular 937. Rome: FAO, 1999.

BUGONI, L.; NEVES, T. S.; LEITE JUNIOR, N. O.; CARVALHO, D.; SALES, G.; FURNESS, R. W.; STEIN, C. E.; PEPPES, F. V.; GIFFONI, B. B.; MONTEIRO, D. S. Potential bycatch of seabirds and turtles in hook-and-line fisheries of the Itaipava Fleet, Brazil. Fish. Res., v. 90, n. 1/3, p. 217-224, 2008.

CADDY, J. F.; GRIFFITHS, R. C. Recursos marinos vivos y su desarrollo sostenible: perspectivas institucionales y medio ambientales. FAO Documento Técnico de Pesca. No. 353. Roma: FAO, 1996. 191 p.

CAMPOS, J. A.; SEGURA, A.; LIZANO, O.; MADRIGAL, E. Ecología básica de Coryphaena hippurus (Pisces: Coryphaenidae) y abundancia de otros grandes pelágicos en el Pacífico de Costa Rica. Rev. Biol. Trop., v. 41, n. 3, p. 783-790, 1993.

CAMPOS, E. J. D.; VELHOTE, D.; SILVEIRA, I. C. Shelf break upwelling driven by Brazil current cyclonic meanders. Geophys. Res. Lett., v. 27, n. 6, p. 751-754, 2000.

CARRUTHERS, E. H.; NEILSON, J. D.; SMITH, S. C. Overlooked bycatch mitigation opportunities in pelagic longline fisheries: soak time and temperature effects on swordfish (Xiphias gladius) and blue shark (Prionace glauca) catch. Fish. Res., v. 108, n. 1, p. 112-120, 2011. 
CARVALHO, F.; MURIE, D.; HAZIN, F. H. V.; HAZIN, H.; LEITE-MOURATO, B.; TRAVASSOS, P.; BURGESS, G. Catch rates and size composition of blue sharks (Prionace glauca) caught by the Brazilian pelagic longline fleet in the southwestern Atlantic Ocean. Aquat. Living Resour., v. 23, n. 4, p. 373-385, 2010.

CERGOLE, M. C.; ÁVILA-DA-SILVA, A. O.; ROSSIWONGTSCHOWSKI, C. L. D. B. Sardinella brasiliensis. In: CERGOLE, M. C.; ÁVILA-DA-SILVA, A. O.; ROSSIWONGTSCHOWSKI, C. L. D. B. (Eds.). Análise das principais pescarias comerciais da região sudeste-sul do Brasil: Dinâmica populacional das espécies em explotação. São Paulo: Instituto Oceanográfico da Universidade de São Paulo. Série Documentos REVIZEE, 2005. p. 145150.

CIRANO, M.; MATA, M. M.; CAMPOS, E. J. D.; DEIRÓ, N. F. R. A circulação oceânica de larga-escala na região oeste do Atlântico sul com base no modelo de circulação global OCCAM. Rev. Bras. Geof., v. 24, n. 2, p. 209-230, 2006.

CLARKE, K. R. Non-parametric multivariate analysis of changes in community structure. Aust. J. Ecol., v. 18, n. 1, p. 117-143, 1993.

DALLAGNOLO, R.; ANDRADE, H. A. Observações a respeito da pescaria sazonal de dourado (Coryphaena hippurus) com espinhel de superfície no sul do Brasil. Bol. Inst. Pesca, v. 34, n. 2, p. 331-335, 2008.

DIAS NETO, J. Pesca no Brasil e seus aspectos institucionais: um registro para o futuro. Rev. CEPSUL: Biodiv Conserv Marinha, v. 1, n. 1, p. 66-80, 2010.

DONOSO, M.; DUTTON, P. H. Sea turtle bycatch in the Chilean pelagic longline fishery in the southeastern Pacific: opportunities for conservation. Biol. Conserv., v. 143, n. 11, p. $2672-2684,2010$.

EVANGELISTA, J. E. V.; OLIVEIRA, G. M.; VASCONCELOS, J. A. Evolução da pesca de atuns no nordeste do Brasil. Bol. Téc. Cient. CEPENE, v. 6, n. 1, p. 77-108, 1998.

GIFFONI, B.; DOMINGO, A.; SALES, G.; NIEMEYERFIEDLER, F.; MILLER, P. Interacción de tortugas marinas (Caretta caretta y Dermochelys coriacea) con la pesca de palangre pelágico en el atlántico sudoccidental: una perspectiva regional para la conservación. Col. Vol. Sci. Pap., v. 62, n. 6, p. 1861-1870, 2008.

HAIMOVICI, M. Recursos pesqueiros demersais da região sul: avaliação do potencial sustentável de recursos vivos da zona econômica exclusiva (REVIZEE). Rio de Janeiro, FEMAR, 1997. $81 \mathrm{p}$

HAIR, J. F.; ANDERSON, R. E.; TATHAM, R. L.; BLACK, W. C. Análise multivariada de dados. Trad. Adonai S. Sant'Anna e Anselmo C. Neto. 5. ed. Porto Alegre: Bookman, 2005.

HAZIN, F. H. V. A pesca na zona econômica exclusiva, ZEE: sua importância para o Brasil. Rev. Bras. Eng. Pesca., v. 1, n. 1, p. 10-18, 2006.

HAZIN, H. G.; HAZIN, F. H. V.; TRAVASSOS, P.; CARVALHO, F. C.; ERZINI, K. Fishing strategy and target species of the Brazilian tuna longline fishery, from 1978 to 2005, inferred from cluster analysis. Col. Vol. Sci. Pap., ICCAT, v. 60, n. 6, p. 2029-2038, 2007a.

HAZIN, H. G.; HAZIN, F. H. V.; TRAVASSOS, P.; CARVALHO, F. C.; ERZINI, K. Standardization of swordfish CPUE series caught by Brazilian longliners in the Atlantic Ocean, by GLM, using the targeting strategy inferred by cluster analysis. Col. Vol. Sci. Pap., ICCAT, v. 60, n.6, p. 2039-2047, 2007 b.
HAZIN, H. G.; HERZINI, K. Assessing swordfish distribution in the South Atlantic based on spatial predictions. Fish. Res., v. 90, p. 45-55, 2008.

HE, X.; BIGELOW, K. A.; BOGGS, C. H. Cluster analysis of longline sets and fishing strategies within the Hawaii-based fishery. Fish. Res., v. 31, p. 147-158, 1997.

KLIPPEL, S.; MARTINS, A. S.; OLAVO, G.; COSTA, P. A. S.; PERES, M. B. Estimativas de desembarque da pesca de linha na costa central do Brasil (estado do Espírito Santo e Bahia) para um ano padrão (1997-2000). In: COSTA, P. A. S.; MARTINS, A. S.; OLAVO, G. (Ed.). Pesca e potenciais de exploração de recursos vivos na região central da Zona Econômica Exclusiva brasileira. Rio de Janeiro: Museu Nacional, 2005. 248 p.

LEWY, P.; VINTHER, M. Identification of Danish North Sea trawl fisheries. ICES J. Mar. Sci., v. 51, p. 263-272, 1994.

LØKKEBORG, S. Rate of release of potential feeding attractants from natural and artificial baits. Fish. Res., v. 8, n. 3, p. 253261, 1990.

LØKKEBORG, S.; PINA, T. Effects of setting time, setting direction and soak time on longline catch rates. Fish. Res., v. 32, n. 3, p. 213-222, 1997.

MARTINS, A. S.; OLAVO, G.; COSTA, P. A. S. A pesca de linha de alto mar realizada por frotas sediadas no Espírito Santo, Brasil. In: COSTA, P. A. S.; MARTINS, A. S.; OLAVO, G. (Ed.). Pesca e potenciais de exploração de recursos vivos na região central da Zona Econômica Exclusiva brasileira. Rio de Janeiro: Museu Nacional, 2005. 248 p.

MARTINS, A. S.; DOXSEY, J. R. Diagnóstico da pesca no litoral do estado do Espírito Santo. In: ISAAC, V. J.; MARTINS, A. S.; HAIMOVICI, M.; ANDRIGUETTO, J. M. (Eds.). A pesca marinha e estuarina do Brasil no início do século XXI: recursos, tecnologias, aspectos socioeconômicos e institucionais. Belém: Universitária UFPA, 2006. p. 93-116.

MAYER, F. P.; ANDRADE, H. A. Captura, esforço e CPUE do espadarte (Xiphias gladius) desembarcado em Santa Catarina em 2000 e 2001. Notas Téc. FACIMAR, v. 7, p. 23-36, 2003.

MAYER, F. P.; ANDRADE, H. A. Swordfish (Xiphias gladius) and blue shark (Prionace glauca) fishery and the dynamics of the fleet off the southeastern Brazilian coast. Col. Vol. Sci. Pap., ICCAT, v. 58, n. 3, p. 1204-1214, 2005.

MAZZOLENI, R. C.; SCHWINGEL, P. R. Elasmobranch species landed in Itajaí Harbor, southern Brazil. Notas Téc. FACIMAR, v. 3, p. 111-118, 1999.

MAZZOLENI, R. C.; SCHWINGEL, P. R. Aspectos da biologia das espécies capturadas por espinhel pelágico na região sul das Ilhas de Trindade e Martin Vaz no verão de 2001. Notas Téc. FACIMAR, v. 6, p. 51-57, 2002.

MENEZES DE LIMA, J. H.; KOTAS, J. E.; LIN, C. F. A historical review of the Brazilian longline fishery and catch of swordfish. Col. Vol. Sci. Pap., ICCAT, v. 51, n. 3, p. 1329$1358,2000$.

MIELKE, P. W.; BERRY, K. J. Permutation Methods: A Distance Function Approach. New York: Springer, 2001.

MOURATO, B. L., ARFELLI, C. A.; AMORIM, A. F.; HAZIN, H. G.; CARVALHO, F. C.; HAZIN, F. H. V. Spatio-Temporal distribution and target species in a longline fishery off the southeastern coast of Brazil. Braz. J. Oceanogr., v. 59, n. 2, p. 185-194, 2011. 
OLSON, D. B.; PODESTÁ, G. P.; EVANS, R. H.; BROWN, O. B. Temporal variations in the separations of Brazil and Malvinas Currents. Deep-Sea Res., v. 35, n. 12, p. 1971-1990, 1988.

PAIVA, M. P. Sobre a pesca dos atuns e afins nas áreas em exploração no Atlântico tropical. Arq. Est. Biol. Mar. Univ. Ceará, Fortaleza, v. 1, n. 1, p. 1-20, 1961.

PANTE, E.; SIMON-BOUHET, B. marmap: A package for importing, plotting and analyzing bathymetric and topographic data in R. PLoS ONE, v. 8, n. 9, p. e73051, 2013.

PINHEIRO, H. T.; MARTINS, A. S.; GASPARINI, J. L. Impact of commercial fishing on Trinidade Island and Martin Vaz Archipelago, Brazil: characteristics, conservation status of the species involved and prospects for preservation. Braz. Arch. Biol. Technol., v. 53, n. 6, p. 1417-1423, 2010.

QUAGGIO, A. L. C.; KOTAS, J. E.; HOSTIM, M. As capturas do tubarão-azul, Prionace glauca Linnaeus (Elasmobranchii, Carcharhinidae), na pescaria de espinhel-de-superfície (monofilamento), sediada em Itajaí (SC), Brasil. Panam. J. Aquat. Sci., v. 3, n. 1, p. 61-74, 2008.

R DEVELOPMENT CORE TEAM. R: A language and environment for statistical computing. R Foundation for Statistical Computing, Vienna, Austria. Available at: $<\mathrm{http} / /$ www.r-project.org/>. Accessed: 2014.

RICKER, W. E. Computation and interpretation of biological statistics of fish population. Bull. Fish. Res. Board Can., v. 191, p. 1-382, 1975.

ROCHA, C. A. S.; CUNHA, V. L.; FERREIRA, A. G. Avaliação das capturas de atuns e afins do nordeste do Brasil, com base em dados obtidos por sensoriamento remoto. Rev. Cient. Fac. Lour. Filho, v. 1, n. 1, p. 41-49, 2001.

ROGERS, J. B.; PIKITCH, E. B. Numerical definition of groundfish assemblages caught off the coast of Oregon and Washington using commercial fishing strategies. Can. J. Fish. Aquat. Sci., v. 49, p. 2648-2656, 1992.

SALAS, S.; GAERTNER, D. The behavior dynamics of fishers: management implications. Fish. Fish., v. 5, p. 153-167, 2004.

SALES, G.; GIFFONI, B. B.; BARATA, P. C. R. Incidental catch of sea turtles by the Brazilian pelagic longline fishery. J. Mar. Biol. Ass. U. K., v. 88, n. 4, p. 853-864, 2008.
SALES, G.; GIFFONI, B. B.; FIEDLER, F. N.; AZEVEDO, V. G.; KOTAS, J. E.; SWIMMER, Y.; BUGONI, L. Circle hook effectiveness for the mitigation of sea turtle bycatch and capture of target species in a Brazilian pelagic longline fishery. Aquat. Conserv. Mar. Freshw. Ecosyst., v. 20, n. 4, p. 428-436, 2010.

SCHWINGEL, P. R.; MAZZOLENI, R. C. Aspectos da biologia das espécies capturadas por espinhel pelágico na costa sul do Brasil no inverno de 2001. Notas Téc. FACIMAR, v. 8, p. 75-82, 2004.

SEELIGER, U.; ODEBRECHT, C.; CASTEllo, J. P. Os Ecossistemas Costeiro e Marinho do Extremo Sul do Brasil. Rio Grande: Ecoscientia, 1998.

STRAMMA, L.; ENGLAND, M. On the water masses and mean circulation of the South Atlantic Ocean. J. Geophys. Res., v. 104, n. C9, p. 2863-2883, 1999.

TEIXEIRA, G. S.; ABDALlAH, P. R.; MOREL, B. B. G. Pesca com embarcações arrendadas no Brasil: uma análise econômica desta atividade no período de 1998 a 2002. CEEMA - Centro de Estudos em Economia e Meio Ambiente. Univ. Rio Grande - FURG, 2002. Available at: < http://www.sober.org.br/ palestra/12/05O298.pdf >. Accessed: Oct 13, 2015.

UNIVALI/CTTMar. Boletim estatístico da pesca industrial de Santa Catarina - Ano 2009 e panorama 2000 - 2009. Itajaí: Universidade do Vale do Itajaí, Centro de Ciências Tecnológicas da Terra e do Mar, 2010. 97 p.

UOZUMI, Y.; NAKANO, H. A historical review of japanese longline fishery and billfishes catches in the Atlantic Ocean. Col. Vol. Sci. Pap., ICCAT, v. 41, p. 233-243, 1994.

WATSON, J. W.; KERSTETTER, D. W. Pelagic longline fishing gear: a brief history and review of research efforts to improve selectivity. Mar. Technol. Soc. J., v. 40, n. 3, p. 6-11, 2006.

WARD, J. H. Hierarchical grouping to optimize an objective function. J. Am. Stat. Assoc., v. 58, p. 236-244, 1963.

WARD, P.; MYERS, R. A. Bait loss its potential effects on fishing power in pelagic longline fisheries. Fish. Res.,v. 86, n. 1, p. 69-76, 2007.

WU, C. L.; YEH, S. Y. Demarcation of operating areas and fishing strategies for Taiwanese longline fisheries in South Atlantic Ocean. Col. Vol. Sci. Pap., ICCAT, v. 52, n. 5, p. 1933-1947, 2001.

ZAVALA-CAMIN, L. A. Distribución vertical y estacional de tunídeos y otras espécies pelágicas en el suoeste y sur del Brasil, obtenida por médio de analysis de contenido estomacal. Col. Vol. Sci. Pap., ICCAT, v. 17, n. 2, p. 439-443, 1982.

\section{ERratum}

Braz. j. oceanogr., vol.63, $\mathrm{n}^{\circ} 4$, pp. 407-422

No Título informado no Sumário, abstract in English | Portuguese, text in English, onde se lê:

Spatio-temporal distribution and target species of longline fish eries off Southeastern/Southern Brazil between 2000 and 2011

Leia-se:

Spatio-temporal distribution and target species of longline fisheries off Southeastern/Southern Brazil between 2000 and 2011 
Fiedler et al.: Spatio-temporal distribution in longline fisheries 